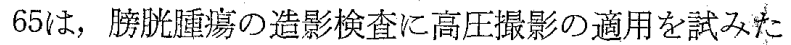
もので，人工膀胱模型を用いて管電圧，造影剤濃度，感 材等について検討し，臨床に適用している。

質問 膀胱造影では，二重造影の方が腫瘍の再現率，描 出率が良いと考えるが，この撮影では腫演の形を見るだ けなのか, 目的は，山本(近畿大)

答 膀胱湩演の形態を見るのが目的で，主に放射線治療 效果の診断に適用している.

66は，膀胱腫锡を対象とした二重膀胱造影にジャイロ スコープを用いて，体位变換を自在に行い，最適造影時 のSpot 撮影を加光診断能の向上を計ったもので，装置 の機能を活用した検查手技の紹介である。

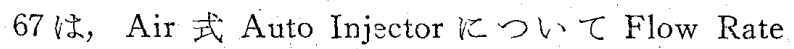
を左右する因子とその寄与摔，対策に関する報告で女 子.

68は，Injector 使用時の注入速度に及ぼす血压の影響 について報告している.

質問 この実験はごの部位を想定して行ったかっ，又注入 量を変光た場合に変化はないか，花山(限大)

答 腹部血管造影を対象にしたものである。造影剂の注 入量を変えてる変らない.

以上，発表及び討論要旨を紹介した。造影撮影に関す る研究恃䛦に直結しているため，医師の協力定要する 場合が多く，研究領域に毛制的を受けるが今後とも更に 研鑚され，より優れた研筧発表を期待したい。

\section{撮影 $-4 \quad$ 拡大・連続他}

座長 伊藤 謙助 (名古屋大学)

\section{9. 選択的血管造影プログラミングの再検討}

盛岡赤十字病院

○市ノ渡憲市・北島 雄次・佐藤 政俊

宫本 岩保・松本，幸夫・吉田 正一 声出 正志

[目的]造影剂, 注入量, 注入時間, 撮影タイミメグ のいわゆるプログラミングは特別な場合を除き，成書を 参考比てさた。しかし過去の経験から反省して選択す る動脈によってプログラミングを再検討し，標準の必要 最小限の造影剤，撮影枚数等を吟味し，日常実施してい る血管造影法について報告する。

[結果] 選択した動脈によって，血流の迅速なる比 較的血流の緩徐のものなど，又年令によって多少の変化 もあるが；おれわれ独自のプログラミングを作成するこ とができ，造影剤の必要最少量や撮影枚数を減少させ ることができたので，“被曝線量の軽減も含めて発表す 万.

\section{0. 選択的冠動脈撮影におけるポジショニングの検討 （第二報）}

金沢医科大学病院中央放射線部 ○三和 秋雄・和泉 長成

石川県立中央病院中央放射線部

笠間 万男・杉村 洋・横山 秀樹

選択的冠動脈撮影に和けるポジショニングについて， 第12回中部々会に和いてそれらについて第 1 報を行った が今回あらたに死後摘出した心蔵の冠動脈に造影剂を注 入し各方向の撮影を行い前回よりる更に詳細に各動脈枝 の出現度とその診断的意義について検討を行った。 その 結果，左右冠動脈ともと正面方向撮影は，背椎の重複 により特別の場合を除き余り好孔いとは言党ず，左冠 動脈性，右前斜位 $40^{\circ} ， 60 \sim 65^{\circ}$, 左前斜位 $60^{\circ}$, 側面, 右冠動脈は，右前斜位 $30^{\circ}$, 左前斜位 $60 \sim 65^{\circ}$, 側面の計 7 万问が良い結果を得ることができた。

\section{Cine Angio における心容量測定法の一考察}

神奈川県立こども医療センター放射線科

○中川 敏夫・湯舟 和雄・小川 雅庸

清水 敦・宮城 哲夫

シネ撮影による心血管造影時の心容量計算のための言! 測は，I.I. 特性や光学系の影響による拡大率の相違やひ ずみを生じ補正が必要である。患者の胸厚に対応してI.I. 面を移動し撮影距離を変化すれば常に同一拡大率の像が 得られる、プロシェクタは機構的に同一拡大の像を投影 する.とこでプロジェクタのスクリーン上で桩大率，ひ ずみを補正した計測用スクリーンを作製し検討した結果， 撮影時に患者胸厚に多わせ I.I. 面位置の設定のみで，ひ ずみの大小にかかわらず容易に補正が行なるる。我々は 各装置毎に，この補正計測用スクリーンを作製し使用す れば容易に測定ができ，日常業務の中では，より有効な 手段である事学確認した。

\section{2. 人エペースメーカー(リチウム電池)の撮影に関す る基礎的検討 （第 2 報） \\ 東京女子医科大学病院放射線科 \\ ○中本 弘二・石川 澄子・高橋 康久 竹山 守}

[目的]，第32回放技学会に於て報告した. 人工ペース メーカカー(リチウム電池)の陰影欠損像の結果及び考察に 基き電池の消耗と，陰影欠損像の関係を追跡し，その経 時的变化について，検討した。

[方法及び考察]リチウム電池を 3 ケ月ごとにX線撮 影し又シンクロスコープで定期測定した結果，端子電圧

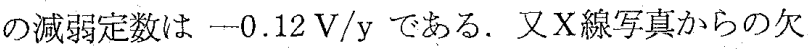
損像面の堌加率を面積比で表示すると $\div 4 \% / \mathrm{y}$ になる。 